\title{
EFEKTIVITAS MODEL PEMBELAJARAN KOOPERATIF DAN MINAT BELAJAR TERHADAP KEWIRAUSAHAAN
}

\author{
Juniati, Sahat Siagian, R. Mursid \\ SMK Negeri 8 Medan, Universitas Negeri Medan \\ Juniati@gmail.com ${ }^{l}$, mursid.tp@gmail.com ${ }^{2}$
}

\begin{abstract}
Abstrak: Penelitian ini bertujuan untuk mengetahui (1) hasil belajar kewirausahaan yang diajar dengan model pembelajaran kooperatif tipe jigsaw lebih tinggi dibandingkan hasil belajar kewirausahaan yang diajar dengan model pembelajaran kooperatif tipe STAD, (2) secara keseluruhan, siswa yang memilki minat belajar tinggi lebih tinggi hasil belajar kewirausahaan, dibandingkan dengan siswa yang memiliki minat belajar, (3) terdapat interaksi antara model pembelajaran dan minat belajar siswa terhadap hasil belajar kewirausahaan. Metode penelitian yang digunakan adalah quasi eksperimen dengan faktorial $2 \times 2$. Teknik analisis yang digunakan adalah analisis varian dua jalur dengan taraf signifikansi $\alpha=0,05$ dengan Uji $F$, pengujian lanjut menggunakan Uji Scheffe. Hasil penelitian menunjukkan (1) Hasil belajar kewirausahaan siswa SMK Negeri 8 Medan yang diajar dengan model pembelajaran kooperatif tipe jigsaw lebih tinggi dibandingkan dengan model pembelajaran kooperatif tipe STAD,pada taraf signifikansi $\alpha=0,05$ dengan $F_{h}$ sebesar 6,49 dan $F_{\text {tabel }}=4,00$, jadi $F_{\text {hitung }}>F_{\text {tabel }}=6,49>4,00$. Hipotesis telah teruji kebenarannya Ha diterima dan Ho ditolak, (2) hasil perhitungan tentang perbedaan hasil belajar kewirausahaan antara kelompok siswa yang memiliki minat belaja rtinggi dan rendah pada taraf signifikansi $\alpha=0,05$ dengan $F_{h}$ sebesar 28,15 dan $F_{\text {tabel }}=4,00 j a d i F_{\text {hitung }}>F_{\text {tabel }}=28,15>4,00$, maka hipotesis telah teruji kebenarannya Ha diterima dan Ho ditolak, (3) besarnya rata-rata hasil belajar kewirausahaan siswa untuk setiap kelompok pembelajaran $\bar{X} A_{1} B_{1}=91,94$ dan $\bar{X} A_{1} B_{2}=78,59$ sedangkan $\bar{X} A_{2} B_{1}=83,06$ dan $\bar{X} A_{2} B_{2}=79,65$. Hasil perhitungan Anava factorial $2 \times 2$ diperoleh hasil perhitungan $F_{h}=8,52$ dan harga tabel $F_{t}=4,00$ adalah $F t_{(0,05)(1,64)}=4,00$, sehingga dapat dinyatakan $F_{h}(8,52)>F_{t}(4,00)$,
\end{abstract}

Kata Kunci: Pengaruh Model, Minat Belajar, Hasil Belajar Kewirausahaan

\begin{abstract}
This research means to know: (1) The learning result of enterprise of student that thought by JIGSAW type cooperative learning model higher than the result of the enterprise which thought by cooperative learning model STAD type.(2) By all the students who have to learn high interest higher than the result of enterprise study compare with the student who has low-interest learning.(3) There is the interaction between the learning model and the learning interest of students to study enterprise from the student. The technic of taking a sample is used sample Cluster Random Sampling based on student interest so that this research sample in learning group and each group consist of 33 students for the experiment, and 35 students for the control group. The research method which used is experiment quasi with factorial $2 \times 2$ analysis technic which used is variant analysis two ways significant level $a=0.05$ by testing $F$, the test continues to use scheffe test. The research result mention = (1) learning result of students enterprise that thought with cooperative learning model JIGSAW type higher than cooperative learning model STAD type, at significant level $a=0.05$ with $F_{h}$ as big as 6.49 and $=4 F_{\text {table }} 00$ so $F_{\text {count }}>F_{\text {table }}=6.49>4.00$ Hypothesis has tasted its correctness $\mathrm{Ha}$ is given and he is refused (2) the calculation result about the difference of learning result enterprise between the group of students who have high study interest and low at a significant level $a=0.05$ with $F a$ as big as 28.15 and $F$ table $=4.00$ so $F$ count $>F_{\text {table }}=28.15>4.00$ so hypothesis has tested its correctness. Ha is given and Ho is refused,(3) its big average the result of students enterprise learning for each learning group $X A_{1} \cdot B_{1}=91.94$ and $X A_{1} B_{2}=78.59$ whereas $X A_{2} B_{1}=83.06$ and $X A_{2} B_{2}=79.65$ the calculation result factorial ANOVA $2 \times 2$ is received the result of calculation $F h=8.52$ and table prise $F 1=4.00$ is $F t(0.05)(1.64)=4.00$
\end{abstract}

Keywords: Effect of Model, Interest Of Student, Result of Enterprise

\section{PENDAHULUAN}

Dalam menghadapi era persaingan global, pemerintah harus mampu menyiapkan SDM yang berkualias dan handal, menyiapkan
SDM yang berkualitas dan handal bisa dilakukan melalui pelatihan keterampilan dan wirausaha.Wirausaha dirasa sangat penting 
untuk meningkatkan perekonomian suatu negara.

pertumbuhan

Dalam rangka mencerdaskan kehidupan bangsa dan Negara pendidikan merupakan unsur utama dan penting. Negara akan maju dan berkembang apabila diikuti dengan peningkatan mutu pendidikan menuju arah yang lebih baik. Kemajuan pendidikan juga akan memberikan dampak positif dalam upaya peningkatan sumber daya manusia, sehingga peningkatan kualitas sumber daya manusia merupakan suatu keharusan bagi bangsa Indonesia pada era globalisasi yang menuntut kesiapan setiap kelompok atau individu bersaing secara bebas,hanya yang berkualitas yang mampu bersaing ataupun berkompetensi.

Tujuan Pendidikan Nasional seperti tercantum dalam UU RI No. 20 tahun 2003 adalah untuk mengembangkan potensi peserta didik agar menjadi manusia bertaqwa kepada Tuhan Yang Maha Esa, berakhlak mulia, sehat, berilmu, cakap, kreatif, mandiri dan menjadi warganegara yang demokratis, serta bertanggung jawab (dalam Departemen Pendidikan Nasional, 2004).

$$
\text { Pendidikan kejuruan yang }
$$

dikembangkan di Indonesia di antaranya adalah Sekolah Menengah Kejuruan (SMK) yang dirancang untuk menyiapkan peserta didik atau lulusan yang siap memasuki dunia kerja dan mampu mengembangkan sikap professional di bidang kejuruan.

Lulusan pendidikan kejuruan diharapkan produktif dan mampu berwirausaha juga dapat menjadi tenaga kerja menengah serta memiliki kesiapan untuk menghadapi persaingan di dunia kerja.

Hadirnya SMK sangat didambakan masyarakat karena lulusan pendidikan kejuruan memang mempunyai kualifikasi sebagai calon tenaga kerja yang memiliki kecakapan dan keterampilan dan dapat terjun kedunia wirausaha tertentu sesuai dengan bidang keahliannya,oleh karena itu kurikulum SMK disusun memperhatikan tahap perkembangan siswa dan kesesuaian dengan jenis pekerjaan, lingkungan sosial, kebutuhan pembangunan nasional, perkembangan ilmu pengetahuan dan teknologi serta kesenian.

Untuk mengetahui pencapaian tujuan pembelajaran tersebut maka pada setiap akhir program pengajaran dilakukan evaluasi.Indikator keberhasilan dari pencapaian tujuan pengajaran tersebut adalah kemampuan belajar siswa yang diwujudkan dalam ujian akhir semester.Dari tiga tahun terakhir yaitu tahun ajaran 2010/2011, 2011/2012 dan 2012/2013, diperoleh rata-rata nilai UAS kewirausahaan, 70, 65, dan 68 (DKN SMK Negeri 8 Medan). Hasil UAS siswa yang masih berada dibatas KKM yang ditetapkan 68 .Hal ini menandakan kuwalitas pendidikan kewirausahaan masih rendah. Penyebab umum atas rendahnya mutu pendidikan kewirausahaan yang secara umum diterima oleh para pendidik kewirausahaan adalah perbedaan asumsi antara siswa dan guru dalam pelajaran kewirausahaan, dimana guru berasumsi bahwa guru dapat memberikan pengajaran yang ada dipikirannya kepada siswa. Dengan asumsi tersebut guru memfokuskan dirinya pada upaya penuangan pengetahuan kedalam pemikiran siswa.

Menurut Bruner dalam Ratna (2002 :48) belajar terdiri dari 3 proses, yaitu: perolehan, transformasi dan evaluasi yang tercakup didalamnya berupa bagaimana memperoleh informasi baru, transformasi informasi tersebut dan menguji relevansi dan ketepatan pengetahuan, adalah merupakan suatu proses interaksi yang dilakukan individu untuk memperoleh sesuatu yang baru dan merubah tingkah laku sebagai hasil pengalaman.

Hasil belajar menurut Arikunto (2003), merupakan suatu hasil yang diperoleh siswa dalam mengikuti suatu proses pembelajaran yang dinyatakan dalam bentuk angka dan hurup.

Romiszowski (1981:242) menyatakan bahwa hasil belajar ditunjukkan dalam bentuk pengetahuan dan ketrampilan. Pengetahuan dikelompokkan dalam empat kategori yaitu ; fakta, konsep, prosedur dan prinsip. Fakta merupakan pengetahuan tentang objek nyata, asosiasi dan kenyataan informasi verbal dari suatu objek.Konsep adalah pengetahuan tentang tindakan yang bersifat linear dalam mencapai tujuan, dan Prinsip adalah pernyataan mengenai hubungan dari dua konsep atau lebih.

Miarso (2005: 530) mengemukakan model pembelajaran adalah pendekatan menyeluruh dalam suatu sistem pembelajaran yang berupa pedomam umum dan kerangka kegiatan untuk mencapai tujuan umum pembelajaran yang dijabarkan dari pandangan falsafah atau teori belajar tertentu. 
Model Pembelajaran Kooperatif adalah salah satu bentuk pembelajaran yang berdasarkan faham kontruktivitis. Pembelajaran kooperatif merupakan model pembelajaran dengan sejumlah siswa sebagai anggota kelompok kecil yang tingkat kemampuannya berbeda.

Model Jigsaw dikembangkan oleh Elliot Aronson dan teman-temannya di Universitas Texas dalam Rusman 2005, Dalam belajar kooperatif tipe jigsaw, siswa dikelompokan sacara heterogen dalam kemampuan.

Siswa diberi materi yang baru atau pendalaman dari materi sebelumnya untuk dipelajari, masing-masing anggota kelompok secara acak, kemudian ditugaskan untuk menjadi ahli (expert) pada satu aspek materi tertentu, dari materi tersebut.setelah membaca dan mempelajari materi, "ahli" dari beberapa kelompok berbeda berkumpul untuk mendiskusikan topik yang sama dari kelompok lain sampai mereka menjadi 'ahli' dikonsep materi yang ia pelajari. Kemudian kembali ke kelompok semula untuk mengajarkan topik yang mereka kuasai kepada teman sekelompoknya. Terakhir diberikan test atau assessment yang lain pada semua topik diberikan.

Pembelajaran tipe Stad merupakan salah satu tipe pembelajaran kooperatip yang menggunakan kelompok kecil didalam pembelajarannya. Setiap kelompok terdiri dari 4-5 orang anggota kelompoknya.

Pembelajaran kooperatif tipe STAD merupakan salah satu tipe dari tipe pembelajaran kooperatif dengan menggunakan kelompok-kelompok kecil dengan jumlah anggota tiap kelompok 4-5 orang siswa secara heterogen. Diawali dengan penyampaian tujuan pembelajaran, penyampaian materi, kegiatan kelompok, kuis, dan penghargaan kelompok.

Slavin (dalam Nurhadi, 2004:26) menyatakan bahwa pada STAD siswa ditempatkan dalam tim belajar beranggotakan 4-5 orang yang merupakan campuran menurut tingkat prestasi, jenis kelamin, dan suku. Guru menyajikan pelajaran kemudian siswa bekerja dalam tim mereka memastikan bahwa seluruh anggota tim telah meguasai pelajaran tersebut. Kemudian seluruh siswa diberikan tes tentang materi tersebut, pada tes ini mereka tidak diperbolehkan saling membantu. Minat merupakan suatu keadaan dimana seseorang mempunyai perhatian dengan objek yang disertai dengan keinginan untuk mengetahui dan mempelajari maupun pembuktian lebih lanjut. Kecenderungan lebih aktif untuk berhubungan dengan objek. Minat adalah sesuatu lebih suka dan rasa keterikatan pada suatu hal atau aktivitas tanpa adanya yang menyuruh. Minat pada dasarnya adalah penerimaan suatu hubungan antara diri sendiri dengan sesuatu diluar diri.Semakin kuat atau dekat hubungan tersebut, semakin besar minatnya. Crow \& Crow (dalam Djaali 2008) mengatakan bahwa minat berhubungan dengan gaya gerak yang mendorong seseorang untuk menghadapi atau berurusan dengan orang, benda, kegiatan, pengalaman yang dirangsang oleh kegiatan itu sendiri.

Minat belajar adalah sesuatu keinginan atau kemauan yang disertai perhatian dan keaktifan yang disengaja yang melahirkan rasa senang dalam perubahan tingkah laku, baik berupa tingkah laku,sikap serta ketrampilan.memiliki unsur afeksi, kesadaran sampai pilihan nilai, pengerahan perasaaan, seleksi, keinginan, dan kecenderungan untuk berbuat terhadap sesuatu.

\section{METODE PENELITIAN}

Populasi dalam penelitian ini adalah seluruh siswa kelas XII (dua belas) bidang keahlian Tata Boga SMK NEGERI 8 Medan terdiri dari 3 kelas yaitu, kelas XII Boga1 $=35$ Orang, XII Boga2 $=33$ Orang, dan XII Boga3= 34 orang, dengan jumlah keseluruhan 102 orang dari keseluruhan populasi ditetapkan 2 kelas yang menjadi sampel.

sampel penelitian diperoleh dengan menggunakan cara cluster random sampling atau teknik pengambilan sampel secara acak sehingga terpilih kelas XII Boga 1 diajar dengan model pembelajaran koperatif tipe jigsaw dan XII Boga 2 diajar dengan model pembelajaran kooperatif tipe STAD.

Metode yang dipergunakan dalam penelitian ini metode quasi eksperimen dengan desain penelitian fakatorial 2X2. Melalui desain ini akan melibatkan dua kelompok sampel masing masing ditetapkan sebagai kelompok eksperimen dengan menggunakan model pembelajaran koperatif tipeJigsaw dan pembelajaran koperatif tipe STAD dalam pelajaran kewirausahaan. 
Model pembelajaran koperatif tipe Jigsaw dan kooperatif tipe STAD sebagai variable bebas sedangkan minat belajar dibagi menjadi minat belajar tinggi dan minat belajar rendah sebagai variable moderator dan hasil belajar pelajaran kewirausahaan sebagai variabel terikat. Untuk melakukan analisis data digunakan tehnik analisis varian dua jalur dengan ANAVA 2 X 2 pada taraf signifikan $5 \%$. Sebelum penggunaan analisis varians ada beberapa persyaratan yang harus dipenuhi, yaitu: (1) data yang digunakan berdistribusi normal, maka dilakukan uji normalitas dengan menggunakan uji Liliefors, (2) harus memiliki varians populasi yang homogen maka harus dilakukan uji homogenitas Varians dengan menggunakan uji F dan uji Barlett, (3) jika hasil pengujian signifikan, untuk melihat interaksi antara variabel manipulasi dan variabel moderator terhadap variabel terikat menggunakan uji Scheffe.

\section{HASIL DAN PEMBAHASAN Hasil}

Untuk keperluan pengujian hipotesis dengan menggunakan teknik analisis anava faktorial 2 x 2 dan uji lanjut Scheffe diperlukan harga rata-rata tiap kelompok, Setelah data diolah dengan anava 2 jalur 2 x 2 maka diperoleh hasil analisis seperti pada tabel 1.

Tabel 1. Ringkasan Hasil Perhitungan ANAVA Faktorial 2 x 2

\begin{tabular}{|c|c|c|c|c|c|c|}
\hline Sumber Variasi & $\mathrm{Dk}$ & JK & RJK & $\mathrm{F}_{\text {hitung }}$ & $\begin{array}{l}\mathrm{F}_{\text {tabel }} \\
\alpha=0,05\end{array}$ & Keterangan \\
\hline $\begin{array}{l}\text { Model pembelajaran } \\
\text { (A) } \\
\text { Minat Belajar (B) } \\
\text { Interaksi (AB) } \\
\text { Galat }\end{array}$ & $\begin{array}{l}1 \\
1 \\
1 \\
65\end{array}$ & $\begin{array}{l}293,11 \\
1271,88, \\
66 \\
2889,88\end{array}$ & $\begin{array}{l}293,11 \\
1271,88 \\
384,66 \\
45,15\end{array}$ & $\begin{array}{l}6,49 \\
28,15 \\
8,52\end{array}$ & $\begin{array}{l}4,00 \\
4,00 \\
4,00\end{array}$ & $\begin{array}{l}\text { Signifikan } \\
\text { Signifikan } \\
\text { Signifikan }\end{array}$ \\
\hline & 68 & 4838,88 & & & & \\
\hline
\end{tabular}

\section{Pengujian hipotesis pertama:}

Hasil Belajar Kewirausahaan Siswa Yang Dibelajarkan dengan Model Pembelajaran Kooperatif Tipe Jigsaw dan Model Pembelajaran Kooperatif Tipe STAD. Pengujian dilakukan terhadap hipotesis statistik yang dirumuskan sebagai berikut :

Ho: $\mu \mathrm{A}_{1} \leq \mu \mathrm{A}_{2}$ Ha: $\mu A_{1}>\mu A_{2}$

Kriteria pernyataan hipotesis adalah jika $F_{h}>F_{t}$ diterima dan Ho ditolak jika $F_{h}>F_{t}$, maka Ha ditolak dan Ho diterima. Hasil perhitungan analisis varians dua jalur dengan tentang perbedaan hasil belajar yang diajar model pembelajaran kooperatif tipe Jigsaw $\bar{X} \mathrm{~A}_{1}$ $=85,46$ dan model pembelajaran kooperatif tipe STAD $\bar{X} \mathrm{~A}_{2}=81,30$, di dapat hasil perhitungan $F_{h}$ sebesar 6,49 dan harga $F_{t}$ untuk taraf signifikansi adalah 4,00 dengan derajat kebebasan $\mathrm{dk}_{(1,64)}$ didapat $\mathrm{F}_{\mathrm{h}}(6,49)>\mathrm{F}_{\mathrm{t}}(4,00)$, sehingga Ho ditolak dan Ha diterima. Dengan demikian temuan penelitian menyimpulkan, bahwa hipotesis penelitian Ha yang berbunyi :Kelompok siswa yang diajar dengan model pembelajaran kooperatif tipe Jigsaw memperoleh hasil belajar kewirausahaan yang lebih tinggi dari siswa yang diajar dengan model pembelajaran kooperatif tipe STAD.pada taraf kepercayaan $\alpha=0,05$ teruji kebenarannya.

\section{Pengujian hipotesis kedua :}

Hasil belajar kewirausahaan siswa yang memiliki minat belajar tinggi dan minat belajar rendah dilakukan dengan analisa varians (ANAVA). Pengujian dilakukan terhadap hipotesis yang dirumuskan sebagai berikut:

Ho: $\mu \mathrm{A}_{1} \mathrm{~B}_{1} \leq \mu \mathrm{A}_{2} \mathrm{~B}_{1}$

$\mathrm{Ha}: \mu \mathrm{A}_{1} \mathrm{~B}_{1}>\mu \mathrm{A}_{2} \mathrm{~B}_{1}$

Kriteria pernyataan hipotesis adalah jika $F_{h}>F_{t}$ diterima dan Ho ditolak jika $F_{h}>F_{t}$, maka Ha ditolak dan Ho diterima. Hasil perhitungan analisis varians tentang perbedaan hasil belajar kewirausahaan antara siswa yang memiliki minat belajar tinggi dengan penerapan pembelajaran model kooperatif tipe Jigsaw rata-rata sebesar $\bar{X} \mathrm{~B}_{1}=87,67$ dan untuk strategi pembelajaran kooperatif tipe STAD rata-rata adalah $\bar{X}_{\mathrm{B}_{2}}=79,12$, di dapat hasil perhitungan $\mathrm{F}_{\mathrm{h}}$ sebesar 28,15 dan harga $F_{t}$ untuk taraf 
signifikansi adalah 4,00 dengan derajat kebebasan $\mathrm{dk}_{(1,65)}$ didapat $\mathrm{F}_{\mathrm{h}}(28,15)>\mathrm{F}_{\mathrm{t}}(4,00)$ sehingga Ho ditolak dan Ha diterima. Dengan demikian temuan penelitian menyimpulkan, bahwa hipotesis penelitian Ha yang berbunyi :Kelompok siswa yang memiliki minat belajar tinggi memperoleh hasil belajar kewirausahaan lebih tinggi dibandingkan dengan kelompok siswa yang memiliki minat belajar rendah telah teruji kebenarannya, pada taraf kepercayaan $\alpha=$ 0,05 .

Pengujian hipotesis ketiga: Interaksi Antara Model Pembelajaran dengan Minat BelajarTerhadap Hasil Belajar. Pengujian dilakukan terhadap hipotesis statistik yang dirumuskan sebagai berikut :

Ho : INT A $><B=0$

Ha : INT A $><B \neq 0$

Kriteria pernyataan hipotesis adalah jika $F_{h}>F_{t}$ diterima dan Ho ditolak jika $F_{h}>F_{t}$ maka Ha ditolak dan Ho diterima. Besarnya rata-rata hasil belajar kewirausahaan untuk setiap kelompok pembelajaran adalah sebagai berikut, untuk $\bar{X} \mathrm{~A}_{1} \mathrm{~B}_{1}=91,94 \operatorname{dan} \bar{X} \mathrm{~A}_{1} \mathrm{~B}_{2}=78,59$ sedangkan $\bar{X} \mathrm{~A}_{2} \mathrm{~B}_{1}=83,06$ dan $\bar{X} \mathrm{~A}_{2} \mathrm{~B}_{2}=79,65$. Hasil perhitungan Anava faktorial $2 \times 2$ diperoleh hasil perhitungan $F_{h}=28,15$ dan harga tabel $F_{t}=4,00$ pada taraf kepercayaan $\alpha=$ 0,05 dengan $\mathrm{dk}=(1,64)$ adalah $\mathrm{Ft}_{(0,05)(1,64)}=$ 4,00 sehingga dapat dinyatakan $\mathrm{F}_{\mathrm{h}}(28,16)>$ $\mathrm{F}_{\mathrm{t}}(4,00)$,Dengan demikian temuan penelitian menyimpulkan, bahwa hipotesis peneitian $\mathrm{Ha}$ yang berbunyi : terdapat interaksi antara model pembelajaran dan minat belajar dalam mempengaruhi hasil belajar kewirausahaan siswa kelas XII Tata Boga SMK Negeri 8 Medan Ha diterima dan Ho ditolak pada taraf kepercayaan $\alpha=0,05$ teruji kebenarannya.

Tabel 2. Ringkasan Hasil Pengujian dengan Menggunakan Uji Scheffe

\begin{tabular}{|l|l|l|l|}
\hline No & $\begin{array}{l}\text { Hipotesis } \\
\text { Statistik }\end{array}$ & $\mathrm{F}_{\text {hitung }}$ & $\begin{array}{l}\mathrm{F}_{\text {tabel }} \\
\alpha=0,05\end{array}$ \\
\hline 1 & $\begin{array}{l}\mathrm{Ho}: \mu \mathrm{A}_{1} \mathrm{~B}_{1}=\mu \mathrm{A}_{2} \mathrm{~B}_{1} \\
\mathrm{Ha}: \mu \mathrm{A}_{1} \mathrm{~B}_{1}>\mu \mathrm{A}_{2} \mathrm{~B}_{1}\end{array}$ & $14,80^{*}$ & 2,76 \\
\hline 2 & $\begin{array}{l}\mathrm{Ho}: \mu \mathrm{A}_{1} \mathrm{~B}_{1}=\mu \mathrm{A}_{1} \mathrm{~B}_{1} \\
\mathrm{Ha}: \mu \mathrm{A}_{1} \mathrm{~B}_{1}>\mu \mathrm{A}_{1} \mathrm{~B}_{2}\end{array}$ & $34,54^{*}$ & 2,76 \\
\hline 3 & $\begin{array}{l}\mathrm{Ho}: \mu \mathrm{A}_{1} \mathrm{~B}_{1}=\mu \mathrm{A}_{2} \mathrm{~B}_{2} \\
\mathrm{Ha}: \mu \mathrm{A}_{1} \mathrm{~B}_{1}>\mu \mathrm{A}_{2} \mathrm{~B}_{2}\end{array}$ & $29,28^{*}$ & 2,76 \\
\hline 5 & $\begin{array}{l}\mathrm{Ho}: \mu \mathrm{A}_{1} \mathrm{~B}_{2}=\mu \mathrm{A}_{2} \mathrm{~B}_{1} \\
\mathrm{Ha}: \mu \mathrm{A}_{1} \mathrm{~B}_{2}>\mu \mathrm{A}_{2} \mathrm{~B}_{1}\end{array}$ & $3,65^{*}$ & 2,76 \\
\hline 5 & $\begin{array}{l}\mathrm{Ho}: \mu \mathrm{A}_{1} \mathrm{~B}_{2}=\mu \mathrm{A}_{2} \mathrm{~B}_{2} \\
\mathrm{Ha}: \mu \mathrm{A}_{1} \mathrm{~B}_{2}>\mu \mathrm{A}_{2} \mathrm{~B}_{2}\end{array}$ & 0,21 & 2,76 \\
\hline 6 & $\begin{array}{l}\mathrm{Ho}: \mu \mathrm{A}_{2} \mathrm{~B}_{1}=\mu \mathrm{A}_{2} \mathrm{~B}_{2} \\
\mathrm{Ha}: \mu \mathrm{A}_{2} \mathrm{~B}_{1}>\mu \mathrm{A}_{2} \mathrm{~B}_{2}\end{array}$ & 2,13 & 2,76 \\
\hline
\end{tabular}

Untuk memvisualisasikan interaksi dan model pembelajaran danminat belajar terhadap kemampuan hasil belajar kewirausahaan, maka di ambil dari rata-rata dari tiap kelompok data

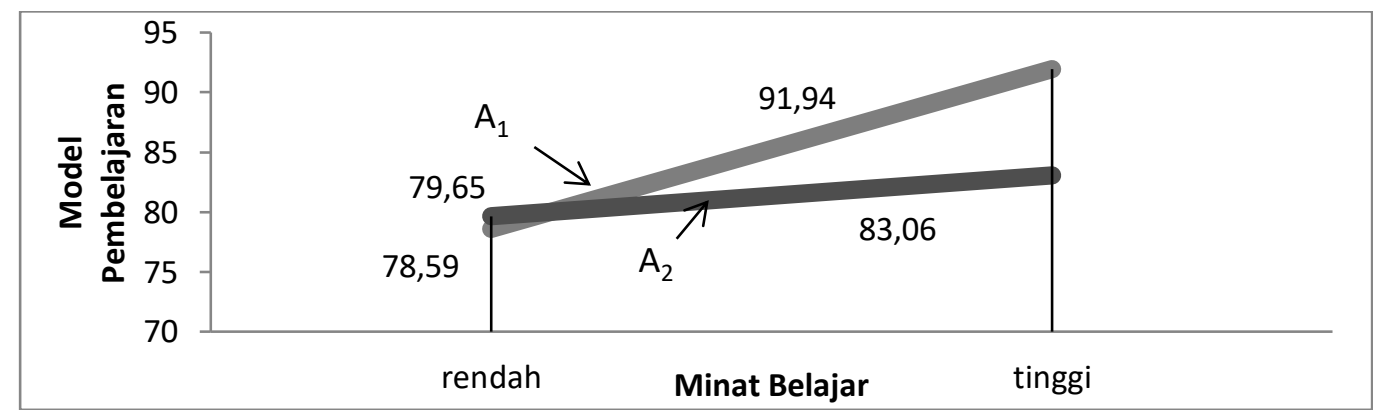

Gambar 1. Interaksi Model Pembelajaran dan Minat Belajar Terhadap Hasil Belajar Kewirausahaan 


\section{Pembahasan}

Berdasarkan pengolahan data diperoleh bahwa Hasil belajar kewirausahaan siswa yang mengikuti pembelajaran dengan model pembelajaran kooperatif tipe Jigsaw lebih tinggi dari pada siswa yang mengikuti pembelajaran dengan model pembelajaran kooperatif tipe STAD., di mana skor rata-rata Hasil belajar kewirausahaan siswa yang mengikuti pembelajaran dengan modelpembelajaran kooperatif tipe Jigsaw lebih tinggi dari pada siswa yang mengikuti pembelajaran dengan model pembelajaran kooperatif tipe STAD. Hal ini disebabkan bahwa model pembelajaran kooperatif tipe Jigsaw lebih baik dalam meningkatkan pemahaman siswa di bandingkan dengan model pembelajaran kooperatif tipe STAD pada taraf signifikansi $5 \%$.

Hasil ini menunjukkan bahwa untuk mengajarkan materi ajar kewirausahaan lebih baik menggunakan model pembelajaran kooperatif tipe Jigsaw dibandingkan model kooperatif tipe STAD.

Penelitian yang dilakukan Hanita (2012) bahwa pembelajaran kooperatif tipe jigsaw dapat meningkatkan keterampilan guru mengelola KBM, meningkatkan kualitas pengelolaan proses belajar mengajar oleh guru, meningkatkan kualitas interaksi siswa dengan lingkungan belajar dan meningkatkan prestasi belajar siswa yang meliputi peningkatan nilai rata-rata dan meningkatkan jumlah siswa yang mencapai ketuntasan belajar.

Model pembelajaran ini didesain untuk meningkatkan rasa tanggung jawab siswa terhadap pembelajarannya sendiri dan juga pembelajaran orang lain. Siswa tidak hanya mempelajari materi yang diberikan, tetapi mereka juga harus siap memberikan dan mengajarkan materi tersebut kepada kelompoknya. Sehingga baik kemampuan secara kognitif maupun sosial siswa sangat diperlukan.

Model pembelajaran Jigsaw ini diladasi oleh teori belajar humanistic, karena teori belajar humanistic menjelaskan bahwa pada hakekatnya setiap manusia adalah unik, memiliki potensi individual dan dorongan internal untuk berkembang dan menentukan perilakunya.

Dalam model pembelajaran kooperatif tipe jigsaw, terdapat kelompok ahli dan kelompok asal.Kelompok asal adalah kelompok awal siswa terdiri dari berapa anggota kelompok ahli yang dibentuk dengan memperhatikan keragaman dan latar belakang. Sedangkan kelompok ahli, yaitu kelompok siswa yang terdiri dari anggota kelompok lain (kelompok asal) yang ditugaskan untuk mendalami topik tertentu untuk kemudian dijelaskan kepada anggota kelompok asal. Disini, peran guru adalah memfasilitasi dan memotivasi para anggota kelompok ahli agar mudah untuk memahami materi yang diberikan.Kunci tipe Jigsaw ini adalah interdependence setiap siswa terhadap anggota tim yang memberikan informasi yang diperlukan. Artinya para siswa harus memiliki tanggunga jawab dan kerja sama yang positif dan saling ketergantungan untuk mendapatkan informasi dan memecahkan masalah yang diberikan.

Hasil penelitian menunjukkan bahwa hasil belajar kewirausahaan siswa yang memiliki minat belajar tinggi, yang mengikuti pembelajaran dengan model pembelajaran kooperatif tipe jigsaw lebih tinggi dari pada siswa yang mengikuti pembelajaran dengan model pembelajaran koop eratif tipe STAD. Hal ini berindikasi bahwa siswa yang memilki kemampuan minat belajar tinggi lebih mampu memahami materi pelajaran kewirausahaan dibandingkan siswa yang memiliki minat belajar rendah.

Minat belajar adalah sesuatu keinginan atau kemauan yang disertai perhatian dan keaktifan yang disengaja yang melahirkan rasa senang dalam perubahan tingkah laku, baik berupa tingkah laku,sikap serta ketrampilan. memiliki unsur afeksi, kesadaran sampai pilihan nilai, pengerahan perasaaan, seleksi, keinginan, dan kecenderungan untuk berbuat terhadap sesuatu.

Winkel (2004) mengemukakan bahwa minat belajar adalah suatu kerangka mental yang terdiri dari kombinasi gerak perpaduan dan campuran dari perasaan, prasangka, cemas dan kecenderungan-kecenderungan, lain yang biasa mengarahkan individu kepada suatu pilihan tertentu. Ahmadi (1992:34) mengemukakan ada tiga aspek-aspek yang mempengaruhi minat belajar antara lain: (1) latihan kebiasaan. Apabila sering melakukan suatu latihan terhadap sesuatu maka akan menyebabkan sesuatu hal tersebut akan menjadi suatu kebiasaan walaupun awalnya merasa tidak ada minat namun karena selalu dilatih 
akan lebih mudah menimbulkan minat pada suatu objek, keterbiasaan akan menimbulkan keterampilan dan kesenangan melakukannya, (2) kebutuhan. Kebutuhan terhadap sesuatu akan memungkinkan timbulnya minat terhadap objek tertentu. Kebutuhan ini akan menjadi pendorong bagi individu untuk mengetahui sesuatu objek yang dijadikan suatu kebutuhan sehingga dapat timbulnya minat untuk mengetahui lebih jauh tentang objek tersebut karena adanya kaitan terhadap diri sendiri, dan (3) ketentuan rangsangan dari objek itu sendiri. Apabila rangsangan kuat dari sesuatu objek maka hal ini berpengaruh besar untuk menarik perhatian dan minat yang datang dari dalam diri individu juga akan semakin meningkat dalam melaksanakan sesuatu objek yang dapat menarik perhatiannya tersebut.

Hasil penelitian menunjukkan bahwa interaksi antara model pembelajaran dengan minat belajar terhadap hasil belajar Kewirausahaan SMK Negeri 8 Medan. Siswa yang memilki minat belajar tinggi dengan mengikuti model pembelajaran kooperatif tipe jigsaw hasil belajarnya lebih tinggi, dibandingkan siswa yang memiliki minat belajar tinggi dengan mengikuti model pembelajaran kooperatif tipe STAD. Demikian pula siswa yang memilki minat belajar rendah dengan mengikuti model pembelajaran kooperatif tipe STAD lebih tinggi, dibandingkan siswa yang memiliki minat belajar rendah dengan mengikuti model pembelajaran kooperatif tipe Jigsaw.Hal ini mengindikasikan adanya interaksi antara model pembelajaran dengan minat belajar terhadap hasil belajar.

Kewirausahaan adalah penerapan kreatifitas dan inovasi untuk memecahkan masalah dan upaya untuk memanfaatkan peluang yang dihadapi setiap hari. Kewirausahaan merupakan gabungan dari kreativitas, inovasi dan keberanian menghadapi resiko yang dilakukan dengan cara kerja keras untuk membentuk dan memelihara usaha baru. Inti dari kewirausahaan adalah kemampuan untuk menciptakan sesuatu yang baru (creative new and different) melalui berpikir kreatif dan bertindak inovatif untuk menciptakan peluang.

$$
\text { Suryana (2008) menjelaskan }
$$

kewirausahaan adalah kemampuan kreatif dan inovatif yang dijadikan dasar, kiat, dan sumber daya untuk mencari peluang menuju sukses.Inti dari kewirausahaan adalah kemampuan untuk menciptakan sesuatu yang baru (creative new and different) melalui berpikir kreatif dan bertindak inovatif untuk menciptakan peluang.

$$
\text { Pada dasarnya kewirausahaan }
$$

merupakan sikap dan perilaku seseorang dalam melakukan suatu kegiatan. Kewirausahaan merupakan proses menciptakan sesuatu yang lain dengan menggunakan waktu dan kegiatan disertai modal dan resiko serta menerima balas jasa dan kepuasan serta kebebasan pribadi.

Pembelajaran kewirausahaan akan memberikan perolehan hasil belajar yang lebih baik melalui belajar bermakna, yakni pembelajaran yang dilakukan dengan modelyang sesuai untuk karakteristik siswa SMK yang memiliki keahlian tertentu dan berhubungan pada kegiatan - kegiatan yang menuntut dorongan dalam diri untuk berbuat lebih baik. Dengan melihat luasnya cakupan dan objek kewirausahaan, maka dibutuhkan siswa yang mampu untuk membangun atau mengkonstruksi sendiri pengetahuan dan keterampilan yang dibutuhkan untuk memecahkan masalahmasalah belajarnya.

Di samping itu siswa harus menemukan sendiri pengetahuan dan keterampilan tersebut, dan bukan karena disampaikan oleh gurunya sendiri. Siswa mampu belajar secara aktif dan mandiri dengan mengembangkan atau menggunakan gagasan dalam menyelesaikan masalah pembelajaran. Dengan demikian pengetahuan dan keterampilan akan dapat diingat dan dipahami dalam jangka memori jangka panjang.

Untuk meningkatkan hasil belajar kewirausahaan dibutuhkan suatu model pembelajaran yang tepat dalam pembelajaran yang efektif dan efesien.Ini sesuai dengan hasil penelitian Temuan penelitian yang dilakukan Sugianto (2014) menemu kan bahwa model pembelajaran tipe Jigsaw lebih baik diajarkan kepada siswa yang mempunyai minat belajar rendah dan model pembelajaran tipe STAD lebih baik digunakan kepada siswa yang mempunya minat belajar tinggi. Minat belajar tinggi jika diajarkan dengan model pembelajaran kooperatif tipe jigsaw akan lebih tepat untuk menumbuhkan minat belajar siswa yang berakibat meningkatkan hasil belajar kewirausahaan. Sedangkan bagi siswa yang memiliki minat belajar rendah kurang mampu berinteraksi bila diajar dengan model pembelajaran kooperatif tipe Jigsaw. Model 
pembelajaran kooperatif tipe jigsaw berupaya untuk dapat menggali pengetahuan kita untuk mampu mengusai materi tentang bagaimana berwirausaha yang sesungguhnya sesuai dengan pandangan dan pengalaman kita sendiri.

Pembelajaran dengan Model pembelajaran koperatif tipe Jigsaw sangat tepat diberikan kepada siswa yang memiliki minat belajar tinggi. Siswa akan aktif membentuk pengetahuan sendiri dengan latihan-latihan yang ada, siswa juga akan merekontruksi pengetahuan yang mengakibatkan hasil belajar siswa akan meningkat. Pembelajaran kooperatif tipe jigsaw dengan urutan penyajian menstimulus siswa untuk mencari dan merekonstruksi sendiri pengetahuan melalui aneka sumber yang tidak hanya bersumber dari guru, sedangkan dalam pembelajaran kooperatif tipe STAD pengetahuan dari siswa sendiri juga bersumber dari guru melalui ceramah atau presentase diruang kelas.Pembelajaran kooperatif tipe jigsaw menuntut siswa berinteraksi dengan kelompok ahli lainnya guna mencari informasi seluasluasnya.

Pada pembelajaran kooperatif tipe STAD interaksi tatap muka antara siswa dan siswa hanya pada satu kelompoknya saja dan dapat dimungkinkan ada siswa yang terkesan sebagai pendengar saja. Akibat perbedaan kedua model pembelajaran yang dilakukan guru ada pengaruh yang berbeda pula terhadap perolehan hasil belajar siswa pada mata pelajaran kewirausahaan. Siswa yang memiliki minat belajar tinggi akan cenderung berperilaku sesuai dengan objek-objek yang dapat memberi nilai yang tinggi.Oleh sebab itu dapat dikatakan bahwa hasil belajar kewirausahaan dipengaruhi oleh model pembelajarn dan minat belajar. Artinya untuk mendapatkan hasil belajar yang baik dengan menggunakan model pembelajaran dengan minat belajar tinggi. Penerapan model pembelajarn kooperatif tipe STAD kepada siswa yang memiliki minat belajar rendah akan mengakibatkan meningkatnya hasil belajar kewirausahan ini disebabkan karena pada pembelajarn dengan model pembelajaran kooperatif tipe STAD peran guru akan lebih banyak untuk membimbing dan memberikan informasi sedangkan siswa akan mendengarkan penjelasan guru dan melakukan kerja kelompok bergabung dengan kelompoknya sendiri, karena siswa tidak dapat belajar mandiri.

Model pembelajaran kooperatif tipe STAD adalah pembelajaran yang juga menekankan penyampaian informasi melalui kerjasama siswa.Hanya aktivitas dikelompok tidak terlalu efektif karena tidak ada pertukaran sesame anggota kelompok, yang artinya dalam satu kelompok dapat saja dimonopoli sseorang siswa yang memiliki antusias lebih tinggi, dan siswa yang kurang antusias hanya aktif pada kegiatan saja. Pembelajaran yang tidak menuntut terlalu banyak aktivitas dan peran aktif siswa akan membuat minat belajarnya menjadi menurun, dan hasil belajarnya menjadi rendah. Dengan demikian siswa yang mempunyai minat belajar rendah akan lebih baik bila diajarkan dengan model pembelajaran kooperatif tipe STAD, sedangkan siswa yang .mempunyai minat belajar tinggi akan lebih tepat bila diajarkan dengan model pembelajaran kooperatip tipe Jigsaw

\section{PENUTUP}

Berdasarkan hasil penelitian dan pembahasan yang telah dikemukakan sebelumnya, maka dapat disimpulkan

1. Hasil belajar kewirausahaan siswa SMK Negeri 8 Medan yang diajar dengan model pembelajaran kooperatif tipe jigsaw lebih tinggi dibandingkan hasil belajar kewirausahaan yang diajar dengan model pembelajaran kooperatif tipe STAD

2. Secara keseluruhan, siswa yang memilki minat belajar tinggi lebih tinggi hasil belajar kewirausahaan SMK Negeri 8 Medan, dibandingkan dengan siswa yang memilki minat belajar rendah.

a. Terdapat interaksi antara model pembelajaran dan minat belajar siswa terhadap hasil belajar kewirausahaan dari siswa SMK Negeri8 Medan.

\section{DAFTAR PUSTAKA}

Ahmadi.1992. Psikologi Umum. Jakarta : Rineka Cipta

Ali, M. 1992. Model Penelitian Pendidikan. Bandung: Angkasa

Arikunto, Suharsimi. 2003. Prosedur Penelitian Suatu Pendekatan Praktik. Jakarta: Bumi Aksara

Arikunto, S. 2002. Dasar-dasar Evaluasi Pendidikan. Jakarta: Bina Aksara 
Arikunto, S. 2006. Dasar-dasar Evaluasi Pendidikan (Ed. Revisi). Jakarta: Bumi Aksara

Asri,Budiningsih. 2005.Belajar dan Pembelajaran. Jakarta : Rineka Cipta

Chalid, S. 2010. Pengaruh Strategi Pembelajaran dan Minat Belajar terhadap Hasil Belajar Menggambar Pola SMK Negeri 8 Medan. Tidak Dipublikasikan. Thesis Medan: PPS Unimed

Dahar, Ratna.W. 2002. Teori-Teori Belajar. Jakarta: Erlangga

Daryanto. 2012. Pendidikan Kewirausahaan Konsep dan Model. Yogyakarta: Gava Media

Departemen Pendidikan Nasional. 2004. Acuan Pelaksanaan Pendidikan Kesetaraan Program Paket ABC. Jakarta: CV Dintam

Dick, W. \& Carey, L.Carey,James O. 2005. The Systematic Design of Instructional. New York: Longman

Dimyati dan Mudjiono. 2006. Belajar dan Pembelajaran. Jakarta: Rineka Cipta

Djaali. 2008. Psikologi Pendidikan. Jakarta: Bumi Aksara

Gagne, Robwer M \& Driscoll, Marcy P. 1989. Essentials of Learning for Instructiom. New Jersey: Prentice Hall

Gerungan. 1991. Psikologi Sosial. Jakarta: Bumi Aksara

Hamalik, Oemar. 2008. Perencanaan Pengajaran Berdasarkan Pendekatan Sistem. Jakarta: Bumi Aksara

Hamid.A. 2007. Teori Belajar dan Pembelajaran. Medan, Program Pascasarjana Unimed

Hergenhahn, B.R. dan Matthew, H.Olson. 2009. Theories of Learning. Jakarta: Kencana

Hanita K Lubis. 2012. Pengaruh Model Pembelajaran Kooperatif dan Intelegensi Terhadap Hasil Belajar Biologi Siswa SMA Al Azhar medan,Tesis Medan:Program Pascasarjana Unimed

Kemp.J.E. 1995. Planing, Producing and Using Instructional Tehnologies. New York: Harper Collins

Miarso, Yusufhadi. 2005. Menyemai Benih, Teknologi Pendidikan. Jakarta: Kencana

Nasution, S. 2006. Kurikulum dan Pengajaran. Jakarta: CV. Mutiara
Natawijaya, Rohman. 1996. Psikologi Pendidikan. Jakarta: Rineka Cipta

Nurhadi. 2004. Kurikulum 2004 Pertanyaan dan Jawaban. Jakarta: PT Gramedia Widiasarana Indonesia

Panjaitan, B. 2006. Karakteristik Pembelajaran dan Kontribusinya Terhadap Hasil Belajar. Medan: Poda

Pusat Statistik. 2014. Data tenaga kerja dan pengangguran Indonesia.

Reigeluth, C.M. 1983. Instructional Design Theory of Models: An Overview of the their Curent Status. London: Prentice Hall

Riyanto, Yatim. 2010. Paradigma Baru Pembelajaran. Jakarta: Kencana

Romizowski,Aj. 1981. Design Instructional System. New York: Nichol Publishing Company

Rusman. 2005. Edisi Kedua. Model-model Pembelajaran. Jakarta: Rinekacipta

Trianto. 2008. Mendisain Pembelajaran Kontesktual. Jakarta: Cerdas Pustaka

Sagala, Syaiful. 2009 . Konsep dan Makna Pembelajaran. Bandung: Alfabeta

Sanjaya, W. 2008. Model Pembelajaran. Jakarta: Kencana

Sardiman, A.M. 2005. Interaksi dan Motivasi Belajar Mengajar. Jakarta: Raja Grafindo Persada

Slamet. 2003. Belajar dan Faktor-Faktor yang Mempengaruhinya. Jakarta: Rineka Cipta

Slavin, Robert. E. 2006. Psikologi Pendidikan: Teori dan Praktek. Jakarta: Indeks

Slavin, Robert. E. 2006. Educational Psychology: Theory And Practice . USA: Pearson Education, Inc

Slavin, Robert. E. 2005. Cooperative Learning: Teori, Riset dan Praktik. Bandung: Nusa Media

Sriani.2013. Pengaruh Metode Pembelajaran dan Kreativitas terhadap Hasil Belajar Kewirausahaan Siswa Kelas XI SMK Negeri 2 Kisaran.Tesis Medan: Program Pascasarjana Unimed

Sudjana. 2005. Metoda Statistika. Bandung: Tarsito

Sudjana,Nana. 2001. Penilaian Hasil Proses Belajar Mengajar. Bandung: Remaja Rosdakarya

Sudjana, N. 1995. Dasar-dasar Proses Belajar Mengajar. Bandung: Sinar Baru 
Sugianto,Dian Armanto. 2014. Perbedaan

Penerapan Model Pembelajaran

Kooperatif tipe Jigsaw dan STAD

Ditinjau dari Kemampuan Penalaran dan komunikasi siswa SMA Negeri 11 Binjai. Jurnal FMIPA, Universitas Negeri Medan.

Suryana. 2008. Kewirausahaan Pedoman Praktis: Kiat dan Proses Menuju Sukses. Bandung: Salemba Empat

Suryabrata,S. 2004. Psikologi Pendidikan. Jakarta: Raja Grafindo Persada

Tracy Brian. The Psychologi of achievement. New York: Simon Schuster

Tsailing Liang. 2002. Implementing Cooperative Learning In EFL Teaching: Process and Effect.Thesis. Institute of English national Taiwan Normal University

Uno,H.B. 2007. Model Pembelajaran Menciptakan Proses Belajar Mengajar yang Kreatif dan Efektif. Jakart: Bumi Aksara

Wibowo, Agus. 2011. Pendidikan Kewirausahaan Konsep dan Model. Yogyakarta: Pustaka Pelajar

Wina, Sanjaya. 2010. Perencanaan dan Desain Sistem Pembelajaran, Jakarta: Kencana Prenada Media Group

Winkel, W.S. 2004. Psikolog Pengajaran, Jakarta: Gramedia 